\title{
Citizenship and Social Policy: the Debate on the Citizen's Income
}

Citoyenneté et politique sociale : le débat sur le revenu de citoyenneté

Jean-Paul Révauger

\section{OpenEdition}

\section{Journals}

\section{Electronic version}

URL: http://journals.openedition.org/rfcb/813

DOI: $10.4000 / \mathrm{rfcb} .813$

ISSN: 2429-4373

\section{Publisher}

CRECIB - Centre de recherche et d'études en civilisation britannique

\section{Electronic reference}

Jean-Paul Révauger, «Citizenship and Social Policy: the Debate on the Citizen's Income », Revue Française de Civilisation Britannique [Online], XXI-1 | 2016, Online since 20 July 2016, connection on 30 April 2019. URL : http://journals.openedition.org/rfcb/813; DOI : 10.4000/rfcb.813

This text was automatically generated on 30 April 2019.

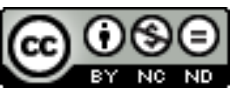

Revue française de civilisation britannique est mis à disposition selon les termes de la licence Creative Commons Attribution - Pas d'Utilisation Commerciale - Pas de Modification 4.0 International. 


\title{
Citizenship and Social Policy: the Debate on the Citizen's Income
}

\author{
Citoyenneté et politique sociale : le débat sur le revenu de citoyenneté
}

Jean-Paul Révauger

\section{Introduction}

1 The current social situation, all over Europe, is dominated by the prevalence of mass unemployment and declining living standards for the wage earning classes, whether they work for the public or the private sector. Short term variations in the unemployment rate enable governments to gloat over the success of their economic policy, as has been the case in the UK since the beginning of 2014, or encourage the opposition to attack governments. In spite of national variations in the unemployment rate across Europe, the long term picture is bleak. The combination of the shift to a post-industrial society, and of neo-liberal social and economic policies, had, by the early years of the $21^{\text {th }}$ century, led to a social model dominated by flexibility, precarious employment and a race towards information technologies. Popular capitalism, owner occupancy, the activation of labour markets made the model attractive at least for a section of the population. The bursting of the Internet financial bubble in March 2000 was the beginning of a long decline, whose rhythm accelerated when the real economy, then transport and tourism were hit. The subprime crisis in 2008 was eventually quelled by governments, at the cost of a huge public deficit, since banks had to be bailed out and saved from bankruptcy. European policies, with the exception of a brief attempt at a Keynesian reflation in the UK under Gordon Brown, remained dominated by the monetarist principles which have been applied since the mid 1970s. The influence of the wage earning classes over society has never been so weak since the 1920s. The social cost of austerity programs all over the EU has been staggering and no solution is in view.

2 In such a context, it is no wonder the search for alternative solutions has been given a fresh impetus. This includes the work of serious economists, like neo-Keynesian and Nobel prize winner Paul Krugman, who seems to exert a much greater influence in the US 
than in the EU. ${ }^{1}$ This quest for fresh ideas also includes some minority currents, some of them probably cranky, although it is hard to tell who will be taken seriously in the future. Hayek and Friedman were for decades seen as dangerous extremists before they became the inspirers of Margaret Thatcher and Ronald Reagan. Among those strange minority currents, this paper is devoted to the study of the movement in favour of a basic universal income, known in the UK as the citizen's income. The contemporary campaign will be briefly analysed, but most of the paper is devoted to a study of the historical sources of the movement in the UK, since the 1920's. The key point made in this chapter is the following: the basic income is not a progressive policy designed to improve the fate of the poor. It is a "safety net" type of benefit, akin to the "Speenhamland system" of the $18^{\text {th }}$ century, the supplementary benefit/income support of the British system and the RMI/ RSA in France. Ironically, it is presented as a revolutionary measure intended to free individuals from the burden of "work". Its philosophy is funded on the idea that work, and in particular waged work, will no longer be the key component of social identity, and will never again be available for all. Social structures will be based on ...other, unspecified factors which are never explicitly defined. The vulgum pecus will be kept at bay, but offered a sufficient pittance to keep it away from mischief, just as the Old Poor Laws became exceptionally generous in the UK during the French Revolution, so as to avoid contagion. Even the French government contemplates a basic income for the under 25, contrary to the RMI/RSA. The basic income is now part of the conservative deal for Europe, the only real question being the amount of the "income", in the context of a budgetary diet. Two alternative policies are on offer: austerity, a "creative life on the dole", and a basic income, or investment in infrastructures, economic stimulation, and a return to growth and job creation.

\section{The movement today}

3 In January 2014, a petition launched under the European Citizen Initiative designed to put a "Citizen's income", known as the "Universal Basic Income" on the agenda of the European Commission was rounded up without meeting its target. The magic number, one million signatures was not met by a long way. ${ }^{2}$ Only 285,000 signatures were collected in favour of the basic income within the lifespan of the initiative, 12 months. In Britain, the petition was not very successful, with only 10,111 signatures, against 40,542 in Germany and 37,415 in France. ${ }^{3}$ The basic income is intended to provide each citizen of a given country with a fixed amount, throughout his/her life, irrespective of age, qualification, work, marital condition, number of children, earned or unearned income, or readiness to work.

4 Its philosophy and aim are rather difficult to grasp. Ostensibly, the citizen's income is straightforward and the rhetoric supporting it surprisingly low key, commonsensical, and apolitical. This is probably one of the reasons for its failure. The citizen's income would be financed through the tax system, and since the amount is uniform, it would be fairly easy to manage. Where supporters diverge is the amount made available to citizens. This is not a technical detail, but affects the whole philosophy of the scheme since a modest amount would merely subsidise low pay, and encourage employers to pay low wages, when a significant amount, in the region of 800 euros per month, would enable people used to a frugal lifestyle to survive without obtaining a regular job. Any money earned on top of the basic income remains in the individual's pocket, and this does not affect the 
amount of the citizen's income. British blue prints for the project quote $£ 71$ per week as a feasible objective, whereas even the French Right is closer to 800 euros per month, roughly twice the British amount.

5 The campaign is led in the UK by two different bodies, the Citizen's Income Trust ${ }^{4}$ on the one hand and the local representatives of the European network known as BIEN (Basic Income European Network), launched in $1986 .{ }^{5}$ The CIT is a lobby, led by Malcolm Torry, the vicar of Holy Trinity Church, Greenwich, a Church of England progressive priest, with an intellectual and academic record at the London School of Economics. It promotes the idea in intellectual and political circles, although it has not met with a lot of success in politics. Not one British MEP signed the European appeal in favour of the citizen's income, a failure which is probably related to the political weakness of the Green party in the UK. Most of the MEPs who did sign were ecologists, such as Eva Joly, José Bové and Yves Cochet in France. Neither Labour nor the Conservatives were involved. The British Greens only have two MEPs, who do not even seem to have signed the petition, which suggests the British campaign is probably different from the continental one, in ideological and political terms. ${ }^{6}$ Reverent Torry, on the LSE web site, writes that "every mainstream political ideology generates arguments for a Citizen's income", and spells them out:

The New Right values the fact that a citizen's income does not disincentivise (sic) enterprise in the way that means-tested benefits do. One Nation conservatives valued the combination of social cohesion and more efficient labour market offered by a Citizen's Income. Liberals value the freedom that a Citizen's Income would give to people to make choices about their employment patterns and relationships. Social democracy values the combination of economic efficiency and redistribution (...) and the Third Way could value a Citizen's Income as a means of reducing poverty in a globalizing economy. ${ }^{7}$

Indeed, the British campaign purports to be ideologically agnostic, or neutral, which is not very convincing. Economic policy is predicated on social and political choices, and not a purely technical issue. Indeed, the arguments deployed in favour of the scheme display a curious similarity with neo-liberal or social liberal discourses. Just because such ideas are commonplace today, it does not mean they can be taken as unchallenged truths. "The best way to ensure the widespread availability of well-paid employment is to make the labour market as free and as flexible as possible"; "A citizen's Income would help reduce the rigidities of the labour market": thus spoke the Citizen's Income Trust in 2013. ${ }^{8}$ This philosophy is closer to that of Margaret Thatcher or Boris Johnson than to the European TUC or progressive Keynesian economists like Paul Krugman. Submitting uncritically to the economic zeitgeist and the dominant or fashionable discourse in Europe is not "apolitical" or "neutral", but sheer conservatism or conformism.

7 Among the frequently asked questions, one finds "would people still work?", an issue clearly liked to the conservative rational choice theory, according to which people always take the best advantage of situations, and only do what is in their best, usually short-term interest. The answer is also quite typical: yes, people would indeed work, since a universal income would remove the poverty trap and other disincentives.

One of the most potent arguments seems to be the reduction in the number of civil servants necessary to administer today's social assistance schemes. There is no denying the Department of Work and Pensions and other social administrations are vast cumbersome bureaucracies, and that the monitoring and surveillance of claimants is 
expensive and time consuming. However, focusing on the absolute need to reduce public spending is again more in tune with neo-liberal discourse than with progressive stances. ${ }^{9}$

\section{Outside Britain}

The ideological slant of the contemporary British movement seems therefore to be somewhat at variance with the French one, which is extremely eclectic and covers a wide span, going from the supporters of Christine Boutin or Dominique de Villepin to the antiglobalisation movement and readers of Le Monde Diplomatique ${ }^{10}$ of the most impeccably radical credentials. The movement is indeed not only pan-European, but international, and experiments carried out in India, Namibia and South America, as part of anti-poverty campaigns, are often quoted in the literature. The scale of the Indian and Namibian experiences seems to be very small, since they are limited to one or a small number of villages. South America is a seething cauldron, where radical movements and experiments sometimes reach national proportions. New forms of democratic representation are indeed tried, and the fascination of old European radicals with developments in Latin America is, up to a point, understandable. However, international comparisons require first and foremost an analysis of contexts, without which no understanding can be reached. It is quite surprising to find references to Alaska alongside comments on India. Indeed, the Republican authorities in Alaska, under Governor Jay Hammond, have since 1976 put aside $25 \%$ of the oil revenue, invested it in the Alaska Permanent Fund, in shares, bonds and real estate, and have paid out an equal sum to all Alaskan citizens. Before the crisis the amount for one year was in excess of $\$ 2,000$; last year in the region of $\$ 900$. It seems the total amount in the fund is in the region of $\$ 40$ Billion. The irony of a situation where Tea Party supporter Sarah Palin doled out money to citizens without any counterpart has been highlighted by many blog users in the US, and Mrs Palin has even been called "a socialist", which is quite unexpected and probably unfair. ${ }^{11}$ Be that as it may, comparing the shrewd use of oil revenues by a no-nonsense capitalist and pro-business administration in the richest country in the world with antipoverty policies in Namibia or India is a tall order, economically, politically, ideologically, in a word, in historical terms.

It is quite clear the global reach of the movement, its "transnational nature" is one of its strengths, since participants feel they are part of a universalist dynamic, but in practice, the national situations vary considerably. This is probably the reason why Europe was chosen as a more realistic target.

\section{The historical roots of the movement in the UK}

In historical terms, the references of the campaign are even more eclectic and misleading. Several texts are available in English, and are used internationally. Even though the movement in Britain is obviously very marginal today, a large proportion of references are British. France is historically the other major contributor. Among the official references the movement wants to promote and stress, some are largely symbolic and rhetorical. Some prestigious authors who made a passing reference to some form or another of basic income are singled out and mentioned systematically, obscure authors are sometimes given prominence when a number of fairly significant movements or individuals are mentioned very briefly. Again, as in geography and contemporary 
references, authors are not presented or classified according to their political leanings. Early supporters of the idea that the state has a specific responsibility towards the poor are dragooned into the basic income brigade, just as the souls of $19^{\text {th }}$ century peasants from the South West of France are claimed by Mormons and registered in their database. Yet, not all social schemes can be considered as forerunners of the "Citizen's income". So references to Vives, and to the old Poor Laws are probably exaggerated. Many references are made to Tom Paine in Basic income literature, but they seem somewhat overenthusiastic and far-fetched. Paine, in a pamphlet written in 1797, "Agrarian Justice", advocated a redistribution of income derived from land ownership to the whole population, through the form of a pension for old people, or a lump sum at adulthood. This amounted to a land tax. He did not advocate a permanent universal income for all citizens.

\section{The Inter war years: Russell, Douglas, Cole}

The period between the two world wars is probably the most significant one as far as the basic income is concerned. Again, Britain is the focal point. There are probably two reasons why original or innovative plans were conceived and promoted, sometimes with some success, during these otherwise sad decades. The first reason is that the government embarked in 1917 in a rhetorical exercise known as "reconstruction". The point was to keep the British population going in spite of the stress of war and war time work, by promising bold reforms. Intellectuals were encouraged to draught blue prints of the "new Britain" that was supposed to be built after the war. The government promises are symbolised by Lloyd George's statement that the authorities would build "homes fit for heroes". Only a handful were built. One of the best minds of the realm, Bertrand Russell, mathematician, philosopher, aristocrat, political and cultural radical produced a well-known book entitled "Principles of social reconstruction". ${ }^{12}$ This was very bold and successful, well beyond the radical circles that, before the war, were attracted by imaginative schemes such as those of the Guild Socialists. ${ }^{13}$ Russell, who had been victimised during the war for his pacifism, became fairly famous. His criticism encompassed the economy, the exploitation of wage labour, but also education, which he found classical and authoritarian, and marriage, which held women in subjection. Russell was extremely sympathetic to the cause of women, whom he loved dearly, and for whom he had a very keen interest. He was also an avowed atheist, which, at the time, was fairly bold. In a word, Russell was a modern thinker who foresaw the importance of issues which only reached the agenda decades later. He was also one of the earliest critics of the USSR. ${ }^{14} \mathrm{He}$ took part in the first visit of left wing intellectuals to Russia, met Lenin, and wrote a devastating book on his return, when so many Fabians, like the Webbs, were sheepishly praising the regime..$^{15}$

13 It is no wonder, with such intellectual and political credentials, that Russell should be found in the pantheon of many innovative currents, and that his name should be associated to such endeavours. There is indeed some evidence that Russell made some reference to a basic income, to be granted to all individuals regardless of their efforts or merits in a book entitled 'Roads to Freedom: Anarchism and Socialism" ${ }^{16}$ But Russell was no economist, he was not a practitioner of the "dismal science" and he only mentioned the need for some sort of universal benefit briefly. The other reason why the interwar years were favourable to social innovation is directly linked to objective developments 
and not to government policy. British industry underwent very rapid changes, whose social impact was tremendous. Whole sectors, such as mining, engineering, textile, declined dramatically, leaving millions out of a job until their last day, while, in other regions, the Fordist system was in full swing. Chemicals, electricity, automobile and aircraft production provided not only employment but reasonable wages, especially compared to pre-1914 levels. Macro-economic management, in particular orthodox monetary policies, geared towards the re-establishment of the gold standard, were severely criticised by Keynes. The similarity between the interwar years and the situation prevailing in Europe since the beginning of the crisis is striking. In both cases, the work process has been revolutionised by technological change, leading to a blurring of traditional social categories, and macro-economic policies obviously led to massive unemployment levels. In other words, the wage earning classes pay the cost of technological change, and most authorities follow the same classical line, sentencing millions to the dole. One had to wait until the mid-1930s for Keynesian policies to be adopted, openly in the US, and de facto in Britain. The combination of a disastrous social situation and counterproductive economic policies encouraged fresh thinking in the 1920s as it does today. The idea was taken up by one of the most fertile brains of the labour movement, GDH Cole. Cole had been fairly experimental before the war, and was one of the intellectual leaders behind the Guild Socialist movement, a grouping of artists and intellectuals, owing partly its origins to the work of William Morris, providing a political, literary and artistic coverage to the Industrial syndicalist movement. Cole was an extremely prolific writer, and published about a hundred books. ${ }^{17} \mathrm{He}$ was clearly on the left of the labour movement, and a supporter of the rather radical New Fabian Research Bureau. Like Russell, he was openly supportive of the "social dividend", but he also supported many other options and causes. The idea of a basic income was not the alpha and the omega of his thinking.

This was not the case of the most influential movement related to the notion, known as the social credit movement. ${ }^{18}$ Even though the economic credentials of the movement were criticised, it was both a typical product of its time, and a minor player on the ideological field. It did have a direct impact on politics in one country, Canada. The views developed by Major Douglas, its chief proponent, were stigmatised and clearly presented as cranky, although not by Keynes, who disagreed on the technical demonstration but shared some of the premises. ${ }^{19}$ James Meade, another Nobel prize winner, wrote in his autobiographical note:

My interest in economics had the following roots. Like many of my generation I considered the heavy unemployment in the United Kingdom in the inter-war period as both stupid and wicked. Moreover, I knew the cure for this evil, because I had become a disciple of the monetary crank, Major C.H. Douglas, to whose works I had been introduced by a much loved but somewhat eccentric maiden aunt. But my shift to the serious study of economics gradually weakened my belief in Major Douglas. ${ }^{20}$

The notion of social credit was based on the idea that every person should receive an unconditional allowance and be given access to consumption. According to Major Douglas the problem affecting the British economy was under-consumption. He shared this analysis with Keynes, even though his economic reasoning was found lacking. Douglas's proposal was therefore to encourage individual consumption. His perspective was not based on state policy, and in this respect he diverged from Keynes, who was concerned with influencing policies and public spending, as well as from the New Deal policies which 
were adopted ten years later in the United States. The state was not to the chief agent of policy, a feature Social Credit has in common with the contemporary supporters of the citizen's income. Douglas shared the defiance of the romantic radical socialists such as the Guild Socialists towards the state. His first article was indeed published by the New Age, a literary journal produced by a distinguished intellectual, Orage, who had actively supported the Guild Socialists before the war. It is no wonder Sidney Webb, the pope of British collectivism, was harshly critical of Social Credit. Politically, Douglas shared the Keynesian criticism of the Bank of England, of conservative policies, and of the governor of the Bank, Montague Norman, who was largely responsible for the Conservatives' strategies of the BoE, and whose effigy was burned publicly. However, he was not clearly aligned with the left. The Labour party was miles away from the prospect of social experiments, and spent much time recovering from the defeat of 1924, the crushing of the General Strike in 1926, MacDonald's defection in $1931 \ldots$ at the hands of the Bank of England. The unions kept aloof from the perspective of Social Credit, and concentrated on their primary function, incomes and working conditions. The hardening of the Means Test after 1931 was seen as evidence of Mac Donald's alignment on the Conservatives. In the long run, this issue remained crucial, but was not embraced by Social Credit at the time. The social creditors refused to be considered as socialists, or as part of the labour movement, which was quite typical of the period.

Douglas's followers in the UK included a lunatic fringe, the "Kibbo craft", a weird outgrowth of the boy-scout movement, which advocated a rural and primitivist philosophy based on the notion of a simple life and devotion to duty. ${ }^{21}$ The group donned a green uniform and marched in several cities, until the banning of private uniforms in 1937. Green bricks were occasionally thrown at 11 Downing Street. It created a Social Credit Party in 1935 but disappeared in 1939. A group seceded from the slightly worrying "Kibbos" and created the Woodcraft Folk, the quite respectable youth organisation of the cooperative movement, which still exists today and has provided outdoor sports and entertainment to the sons and daughters of thousands of left leaning families. ${ }^{22}$

The social credit movement was, understandably, suspected of fascist leanings at the time, and a lot of individuals and movements hesitated between several options. Indeed, the Social Credit Party's love of uniforms and martial antics did have some similarities with fascist organisations. The French rural movement "Chemises vertes", under Roland Dorgères, which ended up supporting Maréchal Pétain during the war, shared the SCP aesthetics, if not their policies. ${ }^{23}$ Political and ideological uncertainty was a feature of the 30 's as well as of the early $21^{\text {st }}$ century. In Canada, the SC party was extremely successful in Alberta. In 1935, it was elected at the head of the province, for a number of years. The lack of a social and ideological culture within the movement explains the crisis which followed this success. The governor insisted on pursuing an orthodox financial policy and refusing to let the public deficit increase - a conservative policy in keeping with his Christian fundamentalist outlook, but which was in clear contradiction with the origins of the movement. Again, this lack of a political culture is a feature the Social Credit movement has in common with the contemporary citizen's income movement. Antiglobalisation activists as well as Social Christians and neo-liberals are to be found among its supporters. Douglas adopted a fairly radical questioning of capitalism and took up again Marx's view on the wage relationship, described as "wage slavery", again, like at least the French supporters of the basic income. He also criticised traditional politics and believed that the role of political institutions should be much simplified and reduced to 
the execution of decisions taken by citizens on an ad hoc basis, through a process of direct representation. Such ideas and criticisms of parliamentary democracy were directly borrowed from the pre-1914 syndicalist movement, and from the Guild Socialists, its intellectual counterpart. Politics as such would become irrelevant, and the secret ballot abolished. Such stances could easily lead the movement towards fascism as well as anarchism. Luckily, the movement disappeared during the war, at least in the UK, although it still has a handful of admirers.

\section{An alternative to the welfare state?}

The Second World War, from a social point of view, is dominated by the overbearing figure of William Beveridge. The struggle against the five giants would indeed be based on universal principles, since everyone would contribute according to their means, and have equal access to services. However, one of the chief characteristics of the welfare state was precisely to supply services directly, and not to enable the population to purchase private services. Education, health, public housing, and, later, transport and energy would be provided by state operated institutions. This was an extremely advanced form of "mixed economy", in which commodification, as we call it today, or "market principles" were shunned. Britain was much more advanced than France in this respect, especially in the field of health, since, in France, provision was and had remained private, with the exception of teaching hospitals.

19 A number of reformers disagreed strongly with Beveridge, in particular a Liberal peer, Juliet Rhys Williams, who proposed a "social contract" based on a benefit conditional upon the person's willingness to work, and enabling the recipient to purchase private services. ${ }^{24}$ The conditionality of the scheme should not be overplayed, since, in 1943 , military or industrial conscription was the rule for the whole population, including women under 50. However, from a political point of view, it is significant to note the evolution of Juliet Rhys Williams, who became an active member of the extremely conservative Monday Club. Her son, Sir Brandon Meredith Rhys Williams, $2^{\text {nd }}$ Baronet, was the Conservative MP for the working class constituency of South Kensington until 1988. He put the case for a basic income in the House of Commons, an argument which bore some similarities with one of the key buzz-words of the neo-liberal current, Milton Friedman's negative income tax.

However, Margaret Thatcher was not prepared to commit herself to a new universal benefit, especially in a decade when social spending actually increased because of the rise of unemployment and the cost of maintaining 12 million people under the poverty line.

\section{Conclusion}

21 The ancestors of the citizen's income cover a surprisingly wide ideological span, from former guild socialists to self-taught economists, cranky middle-aged boy-scouts, academically correct experts, liberal peers and Thatcherite MPs. Its appeal cannot be related to a particular ideological tradition, but, in Britain, to specific issues. The notion of citizenship was grafted recently on that of a more or less unconditional basic income. This probably reflects the interest of British social thinkers for continental ideas. 
In any case, four favourite themes of the citizen's income chime to the ears of British specialists, and are identified as real problems.

The first one, is the question of stigma. From the $19^{\text {th }}$ century onward, poverty has been stigmatised as evidence of a moral fault, and conditional benefits are still based on the distinction between the deserving poor and the undeserving. The means test is one of the key notions of British social policy. It has stigmatised millions of claimants since the days of the Charity Organisation Society and is particularly humiliating. As a public policy, it is central, but it is also hated by the people concerned, and has been combatted by the most advanced and humane social reformers. A universal basic income implies the abolition of the means test, and the removal of stigma.

The second argument is more technical. The basis income would remove the poverty trap, a well-known feature of contemporary social policies. In the current system, whenever unemployed claimants find some work, the income they earn is deducted from their benefit, and they end up with the same amount of money in their pockets. This is a strong disincentive for work. This problem is well known, and many governments, including Britain and France, have started allowing the combination of a full benefit and a small wage, so as to encourage the unemployed to find some work. Clearly an unconditional benefit solves the problem, since it can be combined with any kind of earned income.

5 The third argument reflects the weight of neo-liberal discourse in Britain: the citizen's income would be easy to administer and would allow cuts in the number of people employed by the government to run the existing benefits, and monitor their good use. Reducing the size of government stands out prominently in the communication of the supporters of the citizen's income.

The fourth and last argument is less identifiable ideologically, since it is promoted both by the anti-capitalist left and by neo-liberals. The promotion of individual freedom is the cardinal value cherished in Britain by everyone, to the exclusion of any other. The citizen's income would remove the obligation to work, and devote our lives to boring tasks, thus creating opportunities for many other worthy activities. Whether or not watching television ranks among the alternatives to work is open to question. For neoliberals, doing away with the systematic provision of social services by the state, and enabling citizens to purchase the private services of their choice would open fantastic opportunities, and open widely the avenues of individual freedom.

It is hard to tell whether the idea of a citizen's income has a future. Minority currents and innovative ideas, such as the Tobin tax, have recently resurfaced, sometimes in surprising quarters. ${ }^{25}$ The petition failed in 2014 , but the problems related to social policy seem to be intractable, especially in the context of social and economic policies leading to a decline in living standards. The future is very open.

Jean Paul Révauger, professeur de civilisation britannique à Grenoble, Aix-enProvence, Schoelcher (Martinique) et Bordeaux est un spécialiste de l'histoire des idées et de l'histoire la gauche britannique. Il a publié de nombreux articles comparatifs sur la Grande-Bretagne et la France. 


\section{BIBLIOGRAPHY}

Chollet, Mona, « Une utopie à portée de la main : Imaginer un revenu garanti pour tous. » Le Monde Diplomatique (mai 2013).

Cole, G.D.H., Self Government in Industry (London, Bell, 1917).

Cole, G.D.H., The Next Ten Years in British Social and Economic Policy (London, Macmillan, 1930).

Douglas, Clifford Hugh (aka Major Douglas), Economic Democracy (London, Social Credit

Association, 1920).

Family Allowances and Social Security (London, 1944).

Hutchinson, Frances and Burkitt, Brian, The Political Economy of Social Credit and Guild Socialism (London, Routledge, 1997).

Krugman, Paul, End this Depression! (New York, Melrose Road, 2013).

Krugman, Paul, The Conscience of a Liberal (New York, Norton, 2007).

Krugman, Paul, The Return of Depression Economics (New York, Norton, 2009).

Paxton, Robert, Le temps des chemises vertes. Révoltes paysannes et fascisme rural (Paris, Seuil, 1996).

Révauger, J.P., Le pouvoir aboli, l'autogestion en Grande-Bretagne, 1900-1983. Université de Grenoble III, Thèse d'Etat (1986).

Russell, Bertrand, Principles of Social Reconstruction (London, George Allen \& Unwin, 1917).

Russell, Bertrand, Proposed Roads to Freedom: Anarchism, Socialism, Syndicalism (London, George Allen \& Unwin, 1918).

Russell, Bertrand, The Practice and Theory of Bolchevism (London, George Allen \& Unwin, 1920).

Social Credit (London, 1924).

Webb, Sidney and Webb Beatrice, Soviet Communism, a New Civilisation? (London, Special Edition for Subscribing Members of Trade Unions, 1935).

Williams Rhys, Juliet, Something to Look Forward to (London, 1943).

\section{NOTES}

1. Paul Krugman, The Conscience of a Liberal (New York, Norton, 2007). Paul Krugman, The Return of Depression Economics (New York, Norton, 2009). Paul Krugman, End this Depression! (New York, Melrose Road, 2013).

2. This stands in stark contrast against success of the anti choice lobby, which gathered over 1.8 signatures against "embryo research", under the name of "One of us" campaign.

3. The most enthusiastic supporters were in Bulgaria $(32,000)$, Slovenia $(9,255)$ and Croatia $(12,195)$. This is probably related to the low wages available in central and Eastern Europe, even though the citizen's income would be determined in each country, and would reflect the national conditions. The citizen's income project remains rather modest and does not consider an equalisation of social conditions within the UE. 
4. URL: http://www.citizensincome.org/ (retrieved on 24 May 2016).

5. The web site of the Bien network features a historical presentation of the movement. http:// www.basicincome.org/basic-income/ (retrieved on 24 May 2016).

6. For an analysis by green, anti-growth supporters of the basic wage, see: http:// makewealthhistory.org/2012/07/18/the-citizens-income/ (retrieved on 24 May 2016).

7. URL: http://blogs.lse.ac.uk/politicsandpolicy/archives/34269 (link no longer active).

8. Ibid.

9. One also finds a trace of this debate in Labour ranks, for instance in Scottish Labour: see http://www.labourhame.com/archives/835 (link no longer active).

10. Mona Chollet, «Une utopie à portée de la main : Imaginer un revenu garanti pour tous ", Le Monde Diplomatique (May 2013).

11. See the web site of the Alaska Permanent Fund Corporation, managed by trustees, and owned by the state. URL: http://www.apfc.org/home/Content/home/index.cfm (link no longer active).

See also «Socialist Sarah Palin? »URL: http://teamsternation.blogspot.fr/2012/09/sarah-palinsecret-socialist.html (retrieved on 24 May 2016).

12. Bertrand Russell, Principles of Social Reconstruction (London, George Allen \& Unwin, 1917).

13. On this movement, see GDH Cole's books, such as Self Government in Industry, London, Bell, 1917, as well as J.P. Révauger's doctoral thesis: Le pouvoir aboli, l'autogestion en GB, 1900-1983 (1986).

14. Bertrand Russell, The Practice and Theory of Bolchevism (London, George Allen \& Unwin, 1920).

15. Sidney and Beatrice Webb, Soviet Communism, a New Civilisation? (London, Special Edition for Subscribing Members of Trade Unions, 1935).

16. Bertrand Russell, Proposed Roads to Freedom: Anarchism, Socialism, Syndicalism (London, George Allen\& Unwin, 1918).

17. G.D.H. Cole, The Next Ten Years in British Social and Economic Policy (London, Macmillan, 1930).

18. Clifford Hugh Douglas (aka Major Douglas). Economic Democracy (London, Social Credit Association, 1920); Social Credit. (London, 1924.)

19. The views of the social credit movement are still promoted by a tiny band of sympathisers today: http://www.douglassocialcredit.com/ (retrieved on 24 May 2016).

20. URL: http://www.nobelprize.org/nobel_prizes/economic-sciences/laureates/1977/meadebio.html (retrieved on 24 May 2016).

21. For The adventures of John Hargraves, "White Fox" see: http://www.kibbokift.org/ kkkhist.html (retrieved on 24 May 2016).

22. URL: http://woodcraft.org.uk/ http://woodcraft.org.uk/ (retrieved on 24 May 2016).

23. Robert $O$. Paxton, Le temps des chemises vertes. Révoltes paysannes et fascisme rural (Paris, Seuil, 1996).

24. Juliet Rhys Williams, Something to Look Forward to (London, 1943); Family Allowances and Social Security (London, 1944).

25. «Taxe Tobin: Sarkozy dénonce l'hypocrisie.» Le Figaro, 19 January 2012. http:// www.lefigaro.fr/flash-eco/2012/01/19/97002-20120119FILWWW00526-taxe-tobin-sarkozydenonce-l-hypocrisie.php (retrieved on 24 May 2016) 


\section{ABSTRACTS}

The citizenship income, or « basic income » is an old idea, dating back to the 1920's. Launched by progressive utopians, it was taken up in the 1930's by the Social Credit movement, which hovered between quackery and social experimentation. It was peddled as an alternative to the Beveridgian Welfare State by ultra-liberals, from the 1940's onward, but is also popular among ecologists and anarchists who welcome the end of waged work and of the definition of social identity through work. Today, as an elegant companion for austerity and for the crisis, is it in tune with conservative policies.

Le revenu de citoyenneté, appelé aussi Basic Income, est une vieille idée remontant aux années 1920. Inventée par des utopistes progressistes, elle a été dans les années 1930 reprise à son compte par le mouvement du Social Credit, hésitant entre charlatanisme et expérimentation. Présentée comme une alternative au Welfare State par les ultra libéraux à partir des années 1940, elle est aussi populaire dans le mouvement écolo-libertaire qui souhaite faire son deuil de la société salariale et du rapport au travail. Il s'agit aujourd'hui d'une stratégie d'accompagnement de la crise et de l'austérité, parfaitement compatible avec les politiques publiques conservatrices.

\section{INDEX}

Mots-clés: revenu de citoyenneté, revenu de base, Social Credit, néolibéralisme, utopies, écologie.

Keywords: basic income, citizenship income, Social Credit, neo-liberalism, utopias, ecology

\section{AUTHOR}

\section{JEAN-PAUL RÉVAUGER}

Université Bordeaux-Montaigne 